Louisiana State University

LSU Digital Commons

Faculty Publications

Department of Geology and Geophysics

3-28-2007

\title{
Biogeochemical stoichiometry of Antarctic Dry Valley ecosystems
}

J. E. Barrett

Dartmouth College

R. A. Virginia

Dartmouth College

W. B. Lyons

Byrd Polar and Climate Research Center

D. M. McKnight

University of Colorado Boulder

J. C. Priscu

Montana State University

See next page for additional authors

Follow this and additional works at: https://digitalcommons.Isu.edu/geo_pubs

\section{Recommended Citation}

Barrett, J., Virginia, R., Lyons, W., McKnight, D., Priscu, J., Doran, P., Fountain, A., Wall, D., \& Moorhead, D. (2007). Biogeochemical stoichiometry of Antarctic Dry Valley ecosystems. Journal of Geophysical Research: Biogeosciences, 112 (1) https://doi.org/10.1029/2005JG000141

This Article is brought to you for free and open access by the Department of Geology and Geophysics at LSU Digital Commons. It has been accepted for inclusion in Faculty Publications by an authorized administrator of LSU Digital Commons. For more information, please contact ir@lsu.edu. 


\section{Authors}

J. E. Barrett, R. A. Virginia, W. B. Lyons, D. M. McKnight, J. C. Priscu, P. T. Doran, A. G. Fountain, D. H. Wall, and D. L. Moorhead 
Portland State University

PDXScholar

\title{
Biogeochemical Stoichiometry of Antarctic Dry Valley Ecosystems
}

\author{
John E. Barrett \\ Dartmouth College \\ Ross A. Virginia \\ Dartmouth College \\ W. Berry Lyons \\ Ohio State University \\ Diane M. McKnight \\ University of Colorado at Boulder \\ John Charles Priscu \\ Montana State University - Bozeman
}

See next page for additional authors

Follow this and additional works at: https://pdxscholar.library.pdx.edu/geog_fac

Part of the Environmental Sciences Commons, and the Glaciology Commons Let us know how access to this document benefits you.

\section{Citation Details}

Barrett, J. E., R. A. Virginia, W. B. Lyons, D. M. McKnight, J. C. Priscu, P. T. Doran, A. G. Fountain, D. H. Wall, and D. L. Moorhead (2007), Biogeochemical stoichiometry of Antarctic Dry Valley ecosystems, J. Geophys. Res., 112, G01010, doi:10.1029/2005JG000141.

This Article is brought to you for free and open access. It has been accepted for inclusion in Geography Faculty Publications and Presentations by an authorized administrator of PDXScholar. Please contact us if we can make this document more accessible: pdxscholar@pdx.edu. 


\section{Authors}

John E. Barrett, Ross A. Virginia, W. Berry Lyons, Diane M. McKnight, John Charles Priscu, Peter T. Doran, Andrew G. Fountain, Diana H. Wall, and D. L. Moorhead 


\title{
Biogeochemical stoichiometry of Antarctic Dry Valley ecosystems
}

\author{
J. E. Barrett, ${ }^{1,2}$ R. A. Virginia, ${ }^{1}$ W. B. Lyons, ${ }^{3}$ D. M. McKnight, ${ }^{4}$ J. C. Priscu, ${ }^{5}$ \\ P. T. Doran, ${ }^{6}$ A. G. Fountain, ${ }^{7}$ D. H. Wall, ${ }^{8}$ and D. L. Moorhead ${ }^{9}$ \\ Received 21 November 2005; revised 14 August 2006; accepted 20 October 2006; published 7 February 2007.
}

[1] Among aquatic and terrestrial landscapes of the McMurdo Dry Valleys, Antarctica, ecosystem stoichiometry ranges from values near the Redfield ratios for $\mathrm{C}: \mathrm{N}: \mathrm{P}$ to nutrient concentrations in proportions far above or below ratios necessary to support balanced microbial growth. This polar desert provides an opportunity to evaluate stoichiometric approaches to understand nutrient cycling in an ecosystem where biological diversity and activity are low, and controls over the movement and mass balances of nutrients operate over $10-10^{6}$ years. The simple organisms (microbial and metazoan) comprising dry valley foodwebs adhere to strict biochemical requirements in the composition of their biomass, and when activated by availability of liquid water, they influence the chemical composition of their environment according to these ratios. Nitrogen and phosphorus varied significantly in terrestrial and aquatic ecosystems occurring on landscape surfaces across a wide range of exposure ages, indicating strong influences of landscape development and geochemistry on nutrient availability. Biota control the elemental ratio of stream waters, while geochemical stoichiometry (e.g., weathering, atmospheric deposition) evidently limits the distribution of soil invertebrates. We present a conceptual model describing transformations across dry valley landscapes facilitated by exchanges of liquid water and biotic processing of dissolved nutrients. We conclude that contemporary ecosystem stoichiometry of Antarctic Dry Valley soils, glaciers, streams, and lakes results from a combination of extant biological processes superimposed on a legacy of landscape processes and previous climates.

Citation: Barrett, J. E., R. A. Virginia, W. B. Lyons, D. M. McKnight, J. C. Priscu, P. T. Doran, A. G. Fountain, D. H. Wall, and D. L. Moorhead (2007), Biogeochemical stoichiometry of Antarctic Dry Valley ecosystems, J. Geophys. Res., 112, G01010, doi:10.1029/2005JG000141.

\section{Introduction}

[2] In the McMurdo Dry Valleys of Antarctica (Figure 1), physical processes are the dominant control over ecosystem development, and biological activity is constrained by the timing and spatial distribution of available liquid water; for these reasons the region has been studied as an analog for

\footnotetext{
${ }^{1}$ Environmental Studies Program, Dartmouth College, Hanover, New Hampshire, USA.

${ }^{2}$ Now at Department of Biological Sciences, Virginia Polytechnic Institute and State University, Blacksburg, Virginia, USA.

${ }^{3}$ Byrd Polar Research Center, Ohio State University, Columbus, Ohio, USA.

${ }^{4}$ Institute of Arctic and Alpine Research, University of Colorado, Boulder, Colorado, USA.

${ }^{5}$ Land Resources and Environmental Sciences, Montana State University, Bozeman, Montana, USA.

${ }^{6}$ Earth and Environmental Sciences, University of Illinois at Chicago, Chicago, Illinois, USA.

${ }^{7}$ Department of Geology and Geography, Portland State University, Portland, Oregon, USA.

${ }^{8}$ Natural Resource Ecology Laboratory, Colorado State University, Fort Collins, Colorado, USA.

${ }^{9}$ Earth, Ecological and Environmental Sciences, University of Toledo, Toledo, Ohio, USA.

Copyright 2007 by the American Geophysical Union. 0148-0227/07/2005JG000141
}

understanding surface processes on Mars [Fountain et al., 1999]. In addition to severe physical constraints, the biotic communities are also limited by the availability of organic matter and nutrient elements, which are often present in concentrations too low for growth or in proportions outside the ratios necessary to sustain balanced growth of microbial communities [Priscu, 1995; Nkem et al., 2006]. This unbalanced availability of organic matter and nutrients may further constrain biogeochemical cycling especially for a system so close to the physical limits of life. Application of a stoichiometric framework provides a common currency (i.e., $\mathrm{C}, \mathrm{N}$ and $\mathrm{P}$ ratios) to evaluate the relative influence of biotic vs. abiotic controls over biogeochemical cycling across dry valley landscapes comprising a gradient of biological productivity, i.e., soils, glaciers, streams, and lakes. This approach may also reveal linkages that occur among ecosystems over geological timescales and their response to climate variability [Moorhead et al., 1999; Doran et al., 2002a].

[3] Biogeochemical stoichiometry has provided a useful framework for understanding sources and controls of nutrient availability, and has been widely applied in the study of terrestrial and aquatic ecosystems [Redfield, 1958; Reiners, 1986; Sterner and Elser, 2002; Hessen et al., 2004; Vrede et al., 2004]. Stoichiometric approaches are based on the 


\section{The McMurdo Dry Valleys}

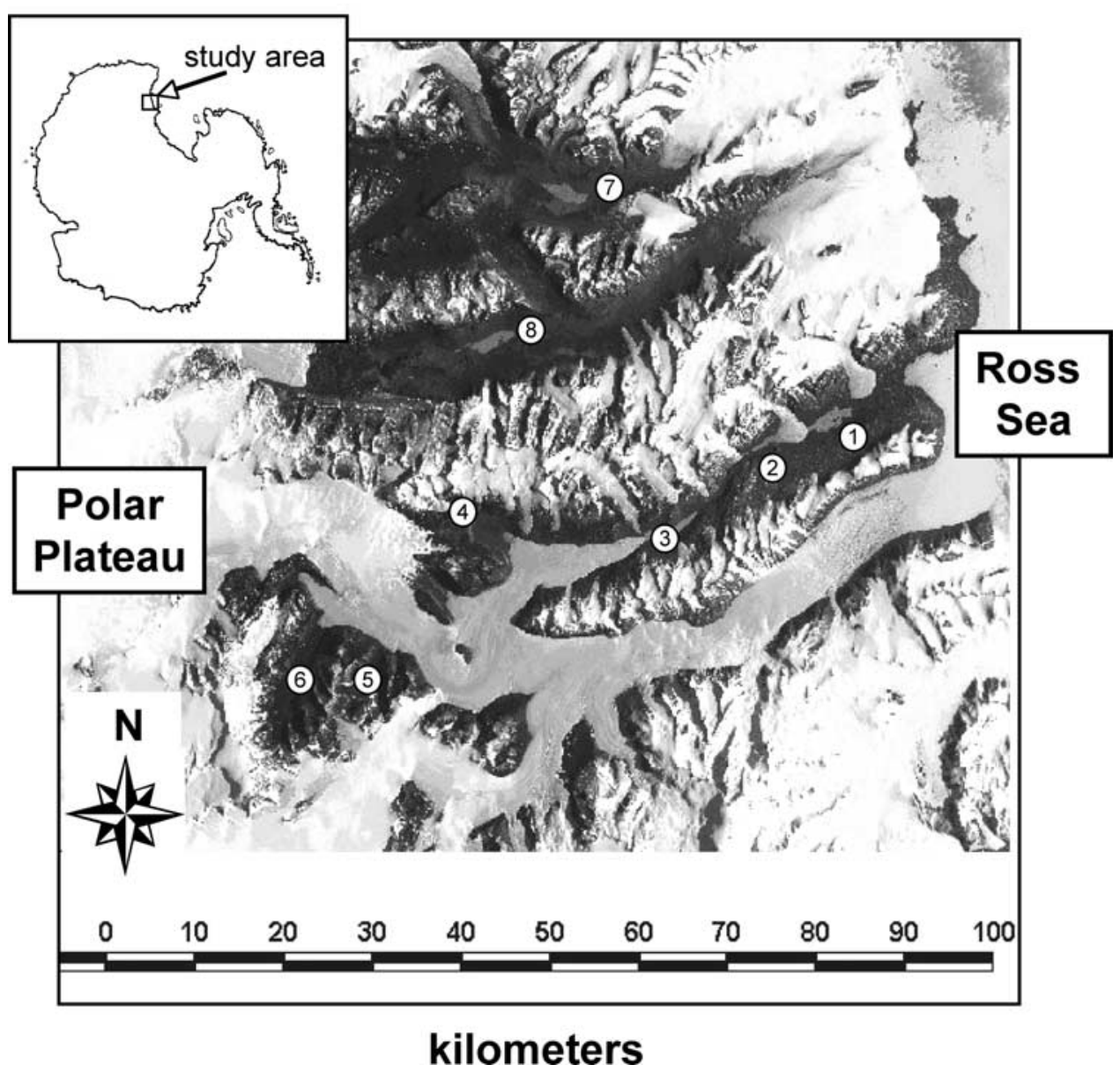

Figure 1. Study sites in the McMurdo Dry Valleys of Southern Victoria Land Antarctica $\left(77^{\circ} \mathrm{S}, 162^{\circ} \mathrm{E}\right)$ : 1, Lake Fryxell; 2, Lake Hoare; and 3, Lake Bonney, Taylor Valley; 4, Lake Joyce, Pearse Valley; 5, Arena Valley; 6, Beacon Valley; 7, Lake Vida, Victoria Valley; 8, Lake Vanda, Wright Valley.

general premise that organisms influence, and are influenced by the chemical composition of their environment, especially the relative availability of essential nutrients. For example, applications of stoichiometry in terrestrial ecosystems have considered how the mass balances and ratios of nutrients are affected by the $\mathrm{N}$ and $\mathrm{P}$ content of resident organisms and their influences over element fluxes, and how the composition and productivity of a community is ultimately constrained by the relative availability of these nutrient elements as they vary over time [Walker and Syers, 1976; Tilman, 1985; Vitousek and Farrington, 1997; Hessen et al., 2004; Wardle et al., 2004]. Geologically young ecosystems are typically rich in $\mathrm{P}$, because primary mineral- $\mathrm{PO}_{4}^{-3}$ is plentiful [Lajtha and Schlesinger, 1988; Filippelli and Souch, 1999], while $\mathrm{N}$ is limiting because $\mathrm{N}_{2}$ fixers have had limited opportunity (time and C-substrate) to increase available $\mathrm{N}$ in the soil [Vitousek and Farrington, 1997]. In contrast, geologically old ecosystems are typically $\mathrm{P}$ limited, and may be regulated by low rates of $\mathrm{P}$ input from dust and eolian redistribution [Chadwick et al., 1999]. Vitousek [2004] describes a clear example of nutrient dynamics influencing ecosystem development (and vice versa) in the Hawaiian Islands, where ecosystems of widely varying age share similar parent material, biota and climate. In sites spanning 4 million years, changes in foliar chemistry and plant nutrient limitations coincided with changes in $\mathrm{N}$ and $\mathrm{P}$ availability [Crews et al., 1995; Vitousek et al., 1995].

[4] Applications of biogeochemical stoichiometry have been most effective in aquatic ecosystems where they are used to describe multiple-element controls over productivity and food web dynamics [Goldman et al., 1979; Hecky and Kilham, 1988; Hassett et al., 1997; Turner, 2002; Wataru and Cotner, 2004]. Progress in understanding the significance of stoichiometry for ecosystem functioning in terrestrial systems has been less successful than in well-mixed aquatic ecosystems where a more homogenous environmental matrix and faster biogeochemical turnover results in dissolved nutrient and planktonic ratios coming to equilibrium with the aqueous environment. This distinction is largely a consequence of a greater prevalence of persistent complex structural material in terrestrial systems (e.g., lignin and cellulose) that does not conform to strict biochemical ratios followed by the largely protoplasmic 
Table 1. Location and Surface Age Estimates for Study Sites

\begin{tabular}{lcccc}
\hline \multicolumn{1}{c}{ Site } & $\begin{array}{c}\text { Latitude, } \\
\text { deg }\end{array}$ & $\begin{array}{c}\text { Longitude, } \\
\text { deg }\end{array}$ & $\begin{array}{c}\text { Elev., } \\
\text { m }\end{array}$ & $\begin{array}{c}\text { Surface Age, } \\
\text { KY }\end{array}$ \\
\hline Fryxell basin, Taylor Valley & $77^{\circ} 37^{\prime}$ & $163^{\circ} 15^{\prime}$ & 55 & $8-24^{\mathrm{a}}$ \\
Commonwealth Glacier & $77^{\circ} 36$ & $163^{\circ} 17^{\prime}$ & 290 & $\ldots$ \\
Canada Glacier & $77^{\circ} 37^{\prime}$ & $162^{\circ} 58^{\prime}$ & 264 & $\ldots$ \\
Hoare basin, Taylor Valley & $77^{\circ} 38^{\prime}$ & $162^{\circ} 53^{\prime}$ & 80 & $75-98^{\mathrm{b}}$ \\
Bonney basin, Taylor Valley & $77^{\circ} 43^{\prime}$ & $162^{\circ} 19^{\prime}$ & 110 & $75-98^{\mathrm{b}}$ \\
Taylor Glacier & $77^{\circ} 44^{\prime}$ & $162^{\circ} 08^{\prime}$ & 334 & $\ldots$ \\
Pearse Valley & $77^{\circ} 43^{\prime}$ & $161^{\circ} 31^{\prime}$ & 420 & N.A. \\
Beacon Valley & $77^{\circ} 50^{\prime}$ & $160^{\circ} 40^{\prime}$ & 1050 & $7000^{\mathrm{c}}$ \\
Arena Valley & $77^{\circ} 52^{\prime}$ & $160^{\circ} 59^{\prime}$ & 1093 & $8000^{\mathrm{c}}$ \\
\hline
\end{tabular}

${ }^{\mathrm{a}}$ Hall and Denton [2000].

${ }^{\mathrm{b}}$ Denton et al. [1989] and Bockheim [2002].

${ }^{\mathrm{c}}$ Marchant et al. [1996].

biomass of aquatic systems, i.e, the Redfield ratio of 106:16:1 C:N:P [Reiners, 1986]. For example, the C:N ratio of algal biomass in the dry valleys is close to the molar Redfield ratio of 6.6:1, whereas a large woody plant has a bulk C:N ratio typically greater than 100:1 [Reiners, 1986].

[5] In the dry valleys, which lack higher plants, the biomass of microbial communities comprising terrestrial and aquatic food webs have narrow physiological constraints governing their biochemical stoichiometry. Thus biotic influences over biogeochemical cycling in extreme ecosystems such as the dry valleys are expected to be expressed as the degree to which the nutrient ratios of their constituent pools and fluxes conform to Redfield stoichiometry. In contrast, where the influence of biota are limited by the physical environment, geochemical processes (e.g., physical weathering, aerosol and eolian deposition) dominate ecosystem stoichiometry.

[6] In this paper we present new data and recently synthesized information from glaciers, streams, lakes and soils gained by a decade of research in the McMurdo Dry Valleys LTER program, a period of observation spanning warm and cold extremes in the recent climate record [Doran et al., 2002b]. Our objectives are to evaluate the relative influences of biotic and abiotic controls over the sources and cycling of nutrients, and consider implications for habitat suitability and the biological productivity of contemporary ecosystems. We hypothesize that direct biotic control over ecosystem stoichiometry is coupled to availability and movement of liquid water, and that legacies of climate and geology regulate sources of nutrient elements and geochemical stoichiometry. We develop a conceptual model that describes the potential for biological modification of solute chemistry coupled to hydrological and eolian transport of $\mathrm{C}, \mathrm{N}$ and $\mathrm{P}$ across landscapes of the dry valleys. We use this model to develop hypotheses describing controls over contemporary nutrient limitation in aquatic ecosystems and the long-term exchanges of nutrient elements among dry valley landscapes.

\section{Methods}

\subsection{Site Description}

[7] The McMurdo Dry Valleys $\left(76^{\circ} 30^{\prime}-78^{\circ} 00^{\prime} \mathrm{S}\right.$, $\left.160^{\circ} 00^{\prime}-165^{\circ} 00^{\prime} \mathrm{E}\right)$ comprise the largest ice-free area $\left(\sim 4800 \mathrm{~km}^{2}\right)$ of the Antarctic continent and occupy a polar desert environment with valley floor mean annual temperatures ranging from $-15^{\circ} \mathrm{C}$ to $-30^{\circ} \mathrm{C}$ and precipitation of less than $10 \mathrm{~cm} \mathrm{yr}^{-1}$ water equivalent [Doran et al., 2002b]. Valley floors typically have fewer than 50 days where average temperatures exceed $0^{\circ} \mathrm{C}$ [Doran et al., 2002b]; hence liquid water is unavailable across much of the landscape for most of the year and is the primary limitation to biological activity and soil weathering. The melting of glaciers provides the primary source of water to dry valley aquatic ecosystems [Fountain et al., 1999]; snow is an important source of water for soils [Gooseff et al., 2003]. Glaciers feed melt-water streams for up to 12 weeks during the summer [McKnight et al., 1999]. Glaciers also harbor simple ecosystems in the surface ice of the ablation zone in cryoconite melt holes that contain biotic communities dominated by algae, cyanobacteria, heterotrophic bacteria, protozoa, rotifers and tardigrades, and may significantly influence melt-water dynamics [Wharton et al., 1985; Fountain et al., 2004].

[8] Streams are an important conduit of material and water across the dry valley landscape, linking glaciers, lakes and soils. Interannual variation in stream flow is large, for example, from $10^{5}$ to $>40^{6} \mathrm{~m}^{3}$ total inflow to Lake Fryxell between 1990 and 2003 [Jaros, 2003]. Stream channels are underlain by a hyporheic zone in the shallow active layer of the permafrost along channel margins where most of the chemical weathering and exchanges between streams and soils occur [Runkel et al., 1998; Nezat et al., 2001; Gooseff et al.,2002; Maurice et al., 2002]. Algal mats colonize streambeds stabilized by stone pavement [McKnight et al., 1998].

[9] Lakes are the only perennial liquid water environments in the dry valleys; they maintain biological activity year-round with food webs dominated by phytoplankton and heterotrophic bacteria [Laybourn-Parry et al., 1997; Priscu et al., 1999; McKnight et al., 2000]. Perennial icecover limits turbulent mixing and most dry valley lakes are strongly stratified by temperature and salinity [Priscu et al., 1999]. The major influences over the chemical composition of dry valley lakes are their landscape positions and climate history [Lyons et al., 2000; Dore and Priscu, 2001].

[10] Arid soils are the most extensive landform of the McMurdo Dry Valleys occupying 95\% of glacier ice-free surfaces below 1000 m [Burkins et al., 2001]. Dry valley soils are derived from tills enriched in granites, sandstones, dolerites and meta-sedimentary rocks that range from Holocene to Miocene in age (Table 1). Soils are typically alkaline, coarse textured, low in organic matter content, and often have high concentrations of soluble salts [Bockheim, 1997]. No vascular plants or vertebrates inhabit the dry valleys, and food webs are dominated by cyanobacteria, algae, bacteria, fungi, yeasts, protozoan and few taxa of metazoan invertebrates [Friedmann et al., 1993; Alger et al., 1997; Laybourn-Parry et al., 1997; Freckman and Virginia, 1997; Priscu et al., 1999; Cowan et al., 2002; Bamforth et al., 2005].

[11] The hydrological mass balances of glaciers, streams, soils and lakes are linked over geological timescales through the inundation and recession of glacial lakes in low-elevation valleys, i.e., Taylor, Wright and Victoria Valleys [Hall et al., 2001, 2002]. High stands of Glacial Lake Washburn inundated Taylor Valley to $\sim 300 \mathrm{~m}$ at 


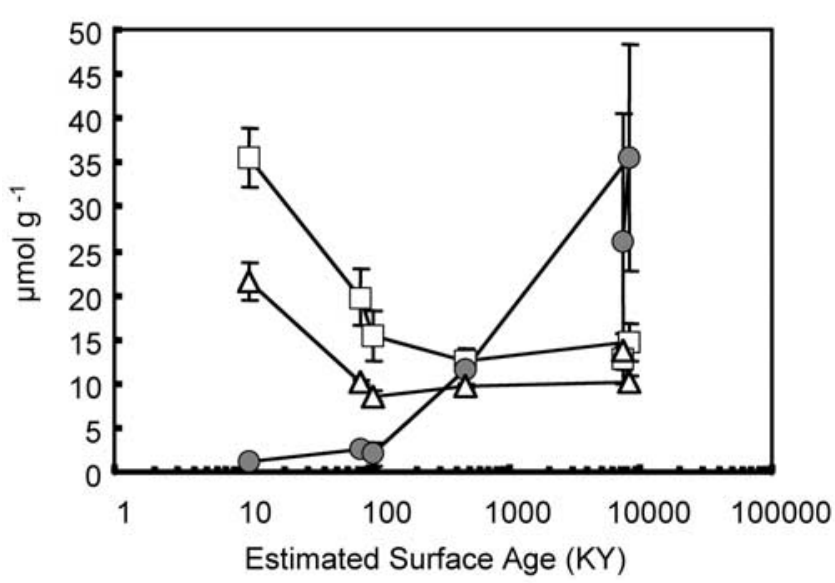

$\rightarrow-$ Soil Organic C $-0-$ Total N $-\Delta-$ Total P

Figure 2. Soil organic carbon, total soil nitrogen and total $\mathrm{HCl}$-soluble phosphorus for soils $(0-10 \mathrm{~cm})$ of the McMurdo Dry Valleys along a surface age gradient. Error bars are \pm 1 SE of the mean. Sources for surface age estimates are given in Table 1.

40000 YPB [Denton et al., 1989]. By about 7000 YBP the West Antarctic Ice Sheet receded and Lake Washburn drained, leaving several smaller lakes impounded in the valley. Subsequent drawdown during a climatic drying period reduced the lakes greatly by $\sim 1000 \mathrm{yr}$ BP [Lyons et al., 2000; Poreda et al., 2004]. Since that time the lakes have refilled to their present state with bottom waters preserving the history of these dry-downs in the elemental composition and stoichiometry of the lake water [Poreda et $a l ., 2004]$. Wright and Victoria Valleys may have experienced similar cycles of lake expansion and recession [Hall et al., 2001, 2002]. Stable isotope composition of soil C and $\mathrm{N}$ pools indicates that a large proportion of contemporary soil organic matter is derived from ancient lacustrine inputs [Burkins et al., 2000]. A lacustrine contribution to contemporary soil organic matter is the basis of the legacy hypothesis, which is a primary theme of the McMurdo Dry Valley LTER program [Moorhead et al., 1999; Burkins et al., 2000; Lyons et al., 2000].

\subsection{Sample Collection and Analysis}

[12] We present original data describing the elemental stoichiometry of dry valley soils, glaciers, streams and lakes based on samples collected between 1991 and 2002, and a synthesis of the recent literature [e.g., Burkins et al., 2000; Dore and Priscu, 2001; Gudding, 2003; Lyons et al., 2003; Foreman et al., 2004, Lawson et al., 2004; Tranter et al., 2004]. Biological data are discussed for soils (presence or absence of invertebrates), glaciers (cryoconites), streams (cyanobacterial mat density) and lakes (phytoplankton productivity) in the context of the stoichiometry of the surrounding soils, sediments and surface waters. Detailed descriptions of sample collection, preparation and analysis, including latitude and longitude, and timing of sampling, are available through the MCM LTER public database at www.memlter.org. All nutrient ratio data are presented in molar units. Statistical analyses were performed using JMP 4.1 (SAS Institute, Cary, NC, USA).

[13] We collected surface soil $(0-10 \mathrm{~cm}$ depth $)$ samples from randomly determined locations in $10 \times 10 \mathrm{~m}$ plots established on level uplands (i.e., away from stream or lake edges) in four of the McMurdo Dry Valleys: Taylor, Pearse, Arena and Beacon (Figure 1). Multiple sites were sampled in Taylor Valley corresponding to long-term data collection and previous studies of major lakes, streams and glaciers. These soils are associated with long-term experiments located in Taylor Valley, and from less intensive sampling in Arena, Beacon and Pearse Valleys spanning the 19992000 and 2000-2001 field seasons. We measured soil organic $\mathrm{C}$ and total soil $\mathrm{N}$, and described and enumerated soil invertebrate communities for the complete set of soil samples $(\mathrm{n}=220)$. Five replicate samples were selected from soils collected from valley floors in each valley and from the three major lake basins in Taylor Valley, and analyzed for soil phosphorus content $(\mathrm{n}=30)$. All soils were collected in polyethylene bags using precleaned $\mathrm{Nasco}^{\mathrm{TM}}$ trowels, stored in ice chests, and transported back to the Crary Analytical Laboratory at McMurdo Station, Antarctica for processing within 48 hours of collection.

[14] Soil invertebrate communities were enumerated using a modified sugar-floatation centrifugation method and inverted light microscopy [Freckman and Virginia, 1997]. In this paper we report only on the presence or absence of identifiable nematode communities. We measured soil inorganic $\mathrm{N}$ content on $\mathrm{KCl}$-extractable pools using a Lachat Quikchem AE Autoanalyzer (Loveland, CO, USA). Bulk organic $\mathrm{C}$ and total $\mathrm{N}$ for soils, sediment and mat material were determined on acidified and unacidified samples using a Carlo Erba Elemental 1500 Analyzer (Milan, Italy). Soil phosphorus content was determined colorimetrically (Lachat Autoanalyzer, or manually on a spectrophotometer) on $\mathrm{HCl}$ soluble fractions [Aspila et al., 1976]. Organic P fractions were estimated from samples combusted at $550{ }^{\circ} \mathrm{C}$ in a muffle furnace [Aspila et al., 1976].

[15] Snow and ice samples were collected from the ablation zones of the Commonwealth $(n=64)$, Canada $(\mathrm{n}=62)$, and Rhone Glaciers $(\mathrm{n}=66)$. Surface snow and ice $(0-5 \mathrm{~cm})$ were collected using acid-rinsed polyethylene bottles [Lyons et al., 2003]. Samples were stored in ice chests and transported to the Crary Analytical Laboratory where they were analyzed on a DX-300 Dionex ion chromatograph (Sunnydale, CA, USA) [Welch et al., 1996]. Only dissolved inorganic $\mathrm{N}$ (DIN: $\mathrm{NH}_{4}^{+}+\mathrm{NO}_{3}^{-}+\mathrm{NO}_{2}^{-}$) and dissolved $\mathrm{PO}_{4}^{-3}$ are reported here.

[16] Stream and lake chemistry data presented here are from annual LTER sampling campaigns conducted between 1991 and 2002. Much of the lake water chemistry has been previously published [Priscu, 1995; Dore and Priscu, 2001; Foreman et al., 2004]. Water samples were collected near stream-monitoring gages or in stream mouths for each stream $(n=907)$. Timing of sampling varied from weekly to annually for different streams over the years studied. Spatial coordinates for collections are available online (see above). Water samples were filtered through precombusted Whatman $25 \mu \mathrm{m} \mathrm{GF} / \mathrm{F}$ filters. Filtrates were collected in acid washed HDPE bottles and stored at $-20^{\circ} \mathrm{C}$ until analysis at the Crary Analytical Laboratory. Analyses for DIN were performed on a Lachat Autoanalyzer. Soluble 
Table 2. Carbon, Nitrogen, and Phosphorus Content of Soils in the McMurdo Dry Valleys ${ }^{\mathrm{a}}$

\begin{tabular}{|c|c|c|c|c|c|c|c|c|}
\hline Site & $\mathrm{SOC}^{\mathrm{b}}$ & $\mathrm{TN}^{\mathrm{c}}$ & $\mathrm{TP}^{\mathrm{d}}$ & Org. $\mathrm{P}^{\mathrm{e}}$ & $C: N^{f}$ & $\mathrm{~N}: \mathrm{P}^{\mathrm{g}}$ & $\mathrm{NO}_{3}^{-}$ & $\mathrm{NH}_{4}^{+}$ \\
\hline Fryxe & $35.8 \mathrm{c}$ & 1.4 & $21.83 \mathrm{a} \pm$ & $4.03 a \pm 1.7$ & $25.08 \mathrm{a} \pm 2.65$ & $0.06 \mathrm{c} \pm 0.01$ & $0.01 \mathrm{~b} \pm 0.01$ & ND \\
\hline Hoare & 2 & 3 & 10.3 & & 29 & 0.2 & & ND \\
\hline Bonney, TV & 2.8 & .3 & 49 & 20 & $6.41 \mathrm{~b}$ & $0.28 c$ & .01 & ND \\
\hline $\mathrm{P}$ & & 1 & $9.98 \mathrm{c}$ & & 1. & & 04 & $.02 \pm 0.01$ \\
\hline Beacon Valley & $13.1 b c \pm 2.9$ & $a \pm 14.5$ & $14.06 b \pm 0.35$ & $1.10 b \pm 0.77$ & $0.50 \mathrm{c} \pm$ & $1.87 \mathrm{a}=$ & $14.93 a=$ & $.04 \pm 0.02$ \\
\hline Arena Valley & $14.9 b c \pm 2.1$ & $35.7 \mathrm{a} \pm 12.8$ & $10.33 b c \pm 0.89$ & $1.25 b \pm 0.48$ & $0.42 \mathrm{c} \pm 1.37$ & $3.46 \mathrm{a} \pm 1.69$ & $43.40 \mathrm{a} \pm 26.16$ & $0.25 \pm 0.14$ \\
\hline
\end{tabular}

${ }^{a}$ Mean surface soil concentration $\left(\mu \mathrm{mol} \mathrm{g}^{-1} \pm 1\right.$ std. dev., $\left.n=30\right)$. Means with the same letter are not significantly different $(\alpha=0.05)$ by analysis of variance and a Tukey-Kramer comparison of means.

${ }^{\mathrm{b}}$ Soil organic C.

${ }^{\mathrm{c}}$ Total soil $\mathrm{N}$.

${ }^{\mathrm{d}}$ Total HCl-soluble P.

e Organic P (by combustion).

${ }^{\mathrm{f}}$ Soil organic C:total soil N.

${ }^{\mathrm{g}}$ Total soil N:total soil P. ND denotes none detected.

Reactive P (SRP) was measured on a Lachat Autoanalyzer or determined manually on a $10 \mathrm{~cm}$ cell using an ammonium molybdate method [Dore and Priscu, 2001].

[17] Algal mat samples were collected from Green Creek and analyzed for their organic matter and $\mathrm{C}, \mathrm{N}$ and $\mathrm{P}$ elemental chemistry. The mats in Green Creek are mainly black and orange morphotypes consisting of Oscillatoriaceae, Nostoc and various diatom species [Alger et al., 1997]. Mat material was scraped from pavement surfaces within the stream channel and transferred to sterile HDPE amber sample bottles. Mat samples were filtered onto precombusted glass fiber filters (Whatman GF/F $45 \mu \mathrm{m}$ ), frozen and stored until analysis. A subset of samples was analyzed for ash-free dry mass (AFDM). Nutrient concentrations of mat material are expressed on an AFDM basis. Total and organic $\mathrm{P}$ fractions were estimated using $\mathrm{HCl} /$ combustion procedures (described above).

\section{Results}

\subsection{Soils}

[18] Soil C, N and P content varied significantly over the range of surface ages among sites in Taylor, Pearse, Beacon and Arena Valleys (Figure 2). Carbon and N contents for the entire data set $(\mathrm{n}=220)$ ranged from maximum concentrations of $69 \mu \mathrm{mol} \mathrm{C}$ (g soil) $^{-1}$ and $580 \mu \mathrm{mol} \mathrm{N}$ (g soil) $^{-1}$, to levels near the detection limits of automated elemental analysis, particularly for soil $\mathrm{N}\left(<1.0 \mu \mathrm{mol} \mathrm{g}^{-1}\right)$. Soil C:N ratios varied widely over the study sites coinciding with differences in climate and elevation; the coldest sites at higher elevations are also older and have higher soil N content (Table 2). Soil invertebrate communities were observed only in samples collected from Taylor Valley where $\mathrm{C}: \mathrm{N}$ ratios were above the Redfield ratio of $6.6: 1 \mathrm{C}: \mathrm{N}$ (Figure 3). Slopes of soil organic $\mathrm{C}$ vs. $\mathrm{N}$ were significant for soils where invertebrates were present $(\mathrm{C}: \mathrm{N}=9.1 \pm 0.8$, $\left.\mathrm{r}^{2}=0.53, \mathrm{P}<0.0001\right)$, but not where they were absent $(\mathrm{C}: \mathrm{N}=0.04 \pm 0.05, \mathrm{P}=0.45)$. Organic $\mathrm{C}$ content was greatest in soils collected from the Fryxell basin in Taylor Valley, and generally declined with surface age from the youngest soils in the Fryxell basin of Taylor Valley to the oldest soils in Beacon and Arena Valleys (Table 2, df $=5$, $\mathrm{F}=10.58, \mathrm{P}=0.0002$, Figure 2). Nitrogen content was greatest in Arena Valley (Table 2, df $=5, \mathrm{~F}=4.6, \mathrm{P}<0.01$, Figure 2), where exchangeable $\mathrm{NO}_{3}^{-}$dominated the soil $\mathrm{N}$ budget. Nitrate concentrations were a large proportion of total soil N in Pearse, Beacon and Arena Valleys (Table 2).

[19] Surface soil P concentrations across these sites were in the range of $8-20 \mu \mathrm{mol} \mathrm{P} \mathrm{g}^{-1}$, with the highest $\mathrm{P}$ concentrations occurring in the soils of Fryxell basin in eastern Taylor Valley (Table 2, $\mathrm{df}=5, \mathrm{~F}=34.5, \mathrm{P}<0.0001$, Figure 2). Soil organic $\mathrm{P}$ followed the same patterns as total $\mathrm{P}$, with values that ranged from 4.6 to $4.0 \mu \mathrm{mol} \mathrm{P} \mathrm{g}^{-1}$. Fryxell soils had the highest organic $\mathrm{P}$ content (Table $2, \mathrm{df}=5$, $\mathrm{F}=3.92, \mathrm{P}<0.018$ ).

\subsection{Glaciers and Streams}

[20] Nitrate concentrations of surface ice on the Commonwealth Glacier were $1.58 \pm 1.19 \mu \mathrm{M} \mathrm{N}$ (mean \pm std. dev.), $1.39 \pm 1.12 \mu \mathrm{M} \mathrm{N}$ on the Canada Glacier, and $2.06 \pm 1.3$ $\mu \mathrm{M} \mathrm{N}$ on the Rhone Glacier. Phosphorus concentrations were very low; $0.08 \mu \mathrm{M}$ P as $\mathrm{PO}_{4}^{-3}$ on the Commonwealth Glacier, and below detection limits for samples collected from the Canada and Rhone Glaciers $(<0.07 \mu \mathrm{M})$.

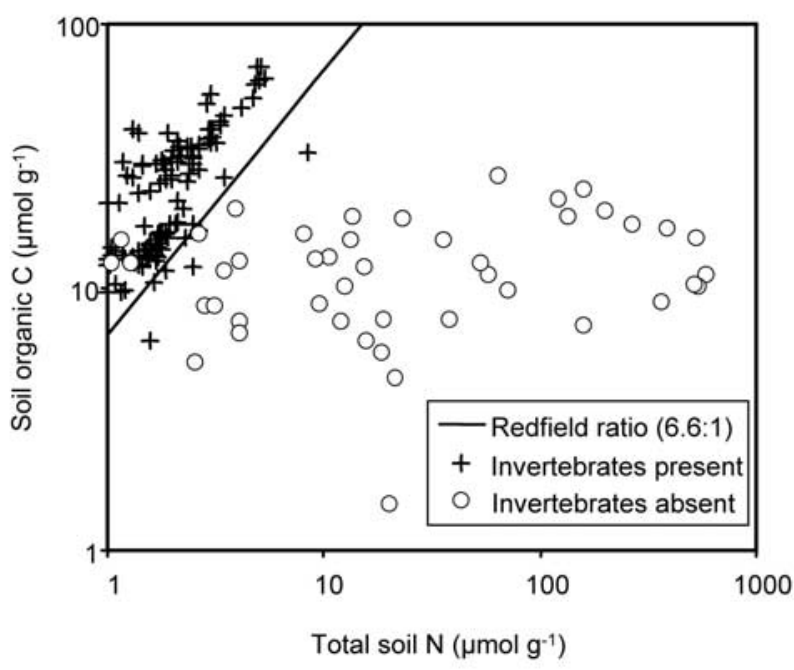

Figure 3. Soil organic $\mathrm{C}$ and total $\mathrm{N}$ content for surface soils $(n=220)$ hosting invertebrate communities (pluses) and soils from locations where no invertebrates were found (circles). The solid line shows the Redfield ratio of 6.61 for $\mathrm{C}: \mathrm{N}$. 
Table 3. Mean ( \pm 1 std. dev.) Dissolved Inorganic N, Soluble Reactive P, and N:P Ratios of Taylor Valley Stream Water (1991-2000)

\begin{tabular}{|c|c|c|c|c|c|c|c|}
\hline \multirow{2}{*}{$\begin{array}{r}\text { Locations } \\
\text { Andrews Creek }\end{array}$} & \multirow[t]{2}{*}{ Visual Algal Abundance } & \multicolumn{2}{|c|}{ DIN $\mu \mathrm{M}-\mathrm{N}^{\mathrm{b}}$} & \multicolumn{2}{|c|}{ SRP $\mu \mathrm{M}-\mathrm{P}^{\mathrm{c}}$} & \multicolumn{2}{|c|}{ Molar N:Pd } \\
\hline & & 2.77 & \pm 1.84 & 0.29 & \pm 0.11 & 19.24 & \pm 38.51 \\
\hline Aiken Creek & & 3.01 & \pm 4.01 & 0.78 & \pm 1.37 & 4.24 & \pm 6.63 \\
\hline Bowles Creek & high & 9.95 & \pm 26.65 & 0.34 & \pm 0.60 & 8.78 & \pm 10.91 \\
\hline Canada Stream & high & 0.99 & \pm 1.71 & 0.29 & \pm 0.83 & 44.38 & \pm 177.99 \\
\hline Crescent Stream & & 0.73 & \pm 0.52 & 0.42 & \pm 0.30 & 1.93 & \pm 1.64 \\
\hline Delta Stream & high & 1.37 & \pm 2.41 & 0.28 & \pm 0.25 & 10.27 & \pm 13.93 \\
\hline Green Creek & high & 3.06 & \pm 12.95 & 0.43 & \pm 0.72 & 6.62 & \pm 10.42 \\
\hline Harnish Creek & & 3.07 & \pm 2.41 & 0.49 & \pm 0.40 & 5.83 & \pm 5.37 \\
\hline Huey Creek & low & 6.11 & \pm 7.33 & 0.71 & \pm 0.81 & 8.36 & \pm 9.21 \\
\hline Lost Seal Stream & & 3.06 & \pm 4.50 & 0.84 & \pm 0.39 & 2.75 & \pm 3.62 \\
\hline Mariah Creek & & 4.92 & \pm 3.97 & 0.56 & \pm 0.40 & 10.14 & \pm 7.50 \\
\hline McKnight Creek & & 0.62 & \pm 0.60 & 0.27 & \pm 0.16 & 2.32 & \pm 1.61 \\
\hline Von Guerard Stream & high & 1.96 & \pm 1.94 & 1.39 & \pm 2.38 & 4.50 & \pm 7.18 \\
\hline Fryxell streams & & $3.16^{\mathrm{b}}$ & \pm 8.25 & 0.40 & $\pm \mathbf{0 . 0 5 7}$ & $9.95^{b}$ & \pm 6.28 \\
\hline Andersen Creek & low & 6.201 & \pm 4.377 & 0.306 & \pm 0.186 & 27.941 & \pm 27.660 \\
\hline House Stream & low & 4.89 & \pm 3.41 & 0.12 & \pm 0.16 & 102.14 & \pm 123.49 \\
\hline McKay Creek & & 2.79 & \pm 1.42 & 0.17 & \pm 0.34 & 257.45 & \pm 808.58 \\
\hline Wharton Creek & low & 4.02 & \pm 2.70 & 0.21 & \pm 0.39 & 43.01 & \pm 36.55 \\
\hline Hoare streams & & $4.83^{b}$ & $\pm \mathbf{1 5 . 4 3}$ & 0.27 & $\pm \mathbf{0 . 1 1}$ & $23.19^{a b}$ & \pm 16.56 \\
\hline Bartlette Creek & & 9.542 & \pm 6.552 & 0.249 & \pm 0.144 & 45.792 & \pm 32.494 \\
\hline Bohner Stream & low & 11.761 & \pm 10.028 & 0.474 & \pm 0.124 & 22.891 & \pm 16.722 \\
\hline Lizotte Creek & & 155.22 & \pm 51.22 & 1.08 & \pm 1.19 & 296.74 & \pm 278.65 \\
\hline Priscu Stream & low & 6.47 & \pm 8.59 & 0.35 & \pm 0.29 & 38.78 & \pm 123.27 \\
\hline Vincent Creek & & 0.59 & \pm 0.66 & 0.28 & \pm 0.31 & 1.69 & \pm 1.01 \\
\hline East Bonney streams & & $43.36^{\mathrm{a}}$ & $\pm \mathbf{1 5 . 4 3}$ & 0.59 & $\pm \mathbf{0 . 1 1}$ & $45.92^{\mathrm{a}}$ & \pm 18.38 \\
\hline Lawson Creek & low & 17.91 & \pm 14.33 & 1.22 & \pm 5.47 & 98.21 & \pm 84.80 \\
\hline Lyons Creek & & 12.21 & \pm 10.51 & 0.32 & \pm 0.36 & 64.13 & \pm 58.54 \\
\hline Red River & & 57.94 & \pm 71.28 & 0.53 & \pm 0.75 & 215.00 & \pm 258.09 \\
\hline Santa Fe Stream & & 11.44 & \pm 16.52 & 0.27 & \pm 0.26 & 70.21 & \pm 121.55 \\
\hline Sharp Creek & & 86.59 & \pm 25.94 & 0.54 & \pm 0.32 & 267.75 & \pm 309.15 \\
\hline West Bonney streams & & $41.69^{\mathrm{a}}$ & \pm 13.80 & 0.41 & $\pm \mathbf{0 . 1 0}$ & $89.27^{\mathrm{a}}$ & \pm 16.44 \\
\hline
\end{tabular}

${ }^{\mathrm{a}} \mathrm{Algal}$ abundance for selected streams are after Alger et al. [1997]. Basin means with different letters denote significant different at $(\alpha=0.05)$.

${ }^{\mathrm{b}}$ One way analysis of variance among basins is: $\mathrm{df}=3, \mathrm{~F}=3.079, \mathrm{P}=0.047$.

${ }^{\mathrm{c}}$ One way analysis of variance among basins is: $\mathrm{df}=3, \mathrm{~F}=1.54, \mathrm{P}=0.23$.

${ }^{\mathrm{d}}$ One way analysis of variance among basins is: $\mathrm{df}=3, \mathrm{~F}=6.21, \mathrm{P}=0.0030$.

[21] Dissolved inorganic N content of stream waters varied significantly across streams among lake basins $(\mathrm{df}=3, \mathrm{~F}=3.08, \mathrm{P}=0.047$ by one-way analysis of variance). Dissolved inorganic $\mathrm{N}$ was lower on average in streams from the Fryxell and Hoare basins (3.16-4.83 $\mu \mathrm{M}$ N) compared to stream water DIN in the Bonney basin (41.69-43.36 $\mu \mathrm{M} \mathrm{N}$ ). Stream water SRP ranged from $0.27-0.40 \mu \mathrm{M}$ P, but differences among streams in different lake basins were not significant $(\mathrm{df}=3, \mathrm{~F}=1.5, \mathrm{P}=0.23$ ). This range of variability in stream water nutrient concentrations resulted in a $>10$ fold difference in N:P ratios in streams across Taylor Valley as a function of location and time of sampling ( $\mathrm{df}=3, \mathrm{~F}=6.21, \mathrm{P}=0.003$, Table 3 ).

[22] Elemental ratios of algal mat material (AFDW) closely resembled the Redfield ratio of 106:16:1. Carbon:P ratios were (mean \pm standard error, $n=30)$ : $107.2( \pm 8.9)$, $\mathrm{N}: \mathrm{P}$ ratios were $11.5( \pm 1.0)$, and $\mathrm{C}: \mathrm{N}$ ratios were $9.4( \pm 0.2)$. Variability in stream water chemistry was strongly associated with the presence of algal mats (Figure 4). Streams with high algal mat density had significantly lower DIN concentration relative to streams with less abundant algal mats $(\mathrm{df}=10, \mathrm{t}=-3.08, \mathrm{P}=0.0012)$, and also marginally lower SRP (d.f. $=10, t=-1.73, P=0.05$ ). Streams with high density of algal mats had a statistically significant

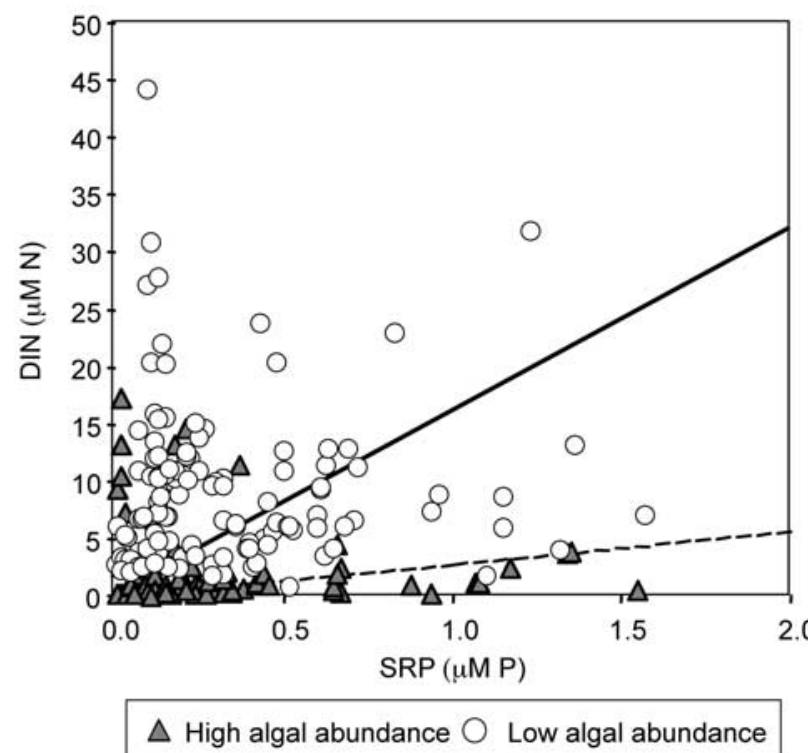

Figure 4. Stream DIN and SRP for streams with high (triangles) and low (circles) algal mat density based on descriptions by Alger et al. [1997]. The solid line shows the Redfield ratio of $16: 1 \mathrm{~N}: \mathrm{P}$, the dashed line is the $\mathrm{N}: \mathrm{P}$ of stream waters from streams with high algal abundance $(2.8 \pm 0.96)$. 
Table 4. Estimated Eolian Sediment and Associated Nutrient (Organic C, Total N, and P) Fluxes From Soils to Taylor Valley Lakes

\begin{tabular}{|c|c|c|c|c|c|c|c|}
\hline & \multirow{2}{*}{$\begin{array}{c}\text { Eolian Sediment } \\
\text { Flux, } \\
\mathrm{g} \mathrm{m}^{-2} \mathrm{yr}^{-1}\end{array}$} & \multicolumn{3}{|c|}{$\begin{array}{c}\text { Eolian } \\
\text { Sediment } \\
\text { Chemistry }^{\mathrm{b}} \\
\mu \mathrm{mol} \mathrm{g}^{-1} \\
\end{array}$} & \multicolumn{3}{|c|}{$\begin{array}{c}\text { Eolian Nutrient } \\
\text { Flux }^{\mathrm{c}} \\
\mathrm{kg} \mathrm{yr}^{-1} \\
\end{array}$} \\
\hline & & $\mathrm{C}$ & $\mathrm{N}$ & $\mathrm{P}$ & $\mathrm{C}$ & $\mathrm{N}$ & $\mathrm{P}$ \\
\hline Lake Fryxell & 1.00 & 42.9 & 2.1 & 26.0 & 3.7 & 0.2 & 5.7 \\
\hline Lake Hoare & 0.86 & 39.5 & 5.6 & 11.5 & 0.8 & 0.1 & 0.6 \\
\hline Lake Bonney & 110.53 & 33.5 & 4.8 & 11.0 & 213.0 & 35.5 & 181.1 \\
\hline
\end{tabular}

${ }^{\mathrm{a}}$ Lancaster [2002].

${ }^{\mathrm{b}}$ Gudding [2003] and MCM-LTER unpublished data (J. Barrett, 2004).

${ }^{\mathrm{c}}$ Calculated with lake surface areas from Lyons et al. [2000].

regression of $\mathrm{N}$ vs. $\mathrm{P}$ with a slope term or $\mathrm{N}: \mathrm{P}$ ratio of $2.8 \pm 0.96(\mathrm{DIN}=2.8 * \mathrm{SRP}, \mathrm{P}=0.004)$. Water chemistry in streams without dense algal mats was much more variable, and the slope of the regression between $\mathrm{N}$ and $\mathrm{P}$ (i.e., the $\mathrm{N}: \mathrm{P}$ ratio) was not significant (Figure 4). A test for similarity of slopes indicated that $\mathrm{N}: \mathrm{P}$ ratios for stream waters where algal mats are dense are significantly lower than where algae are sparse $(\mathrm{df}=132, \mathrm{t}=-2.02, \mathrm{P}<0.04)$. There were exceptions to this trend in a high-flow year, 1991 [Jaros, 2003; Foreman et al., 2004]; in Green Creek and Canada Stream the DIN content was 1-2 orders of magnitude above average levels, generating stream water $\mathrm{N}: \mathrm{P}$ in the range of $100-1000$ that are well above the ratio for balanced growth.

\section{Discussion}

[23] Wind and water link landscapes of the dry valleys [Lyons et al., 2003; Lancaster, 2002], and biological processes alter the geochemical stoichiometry of liquid water as it is generated on the glaciers, flows through the streams and enters closed catchment lakes. Evidence for a large biological influence over stoichiometry in the soils is lacking. However, soils provide an important source of nutrients, particularly $\mathrm{N}$ and $\mathrm{P}$ to lakes via eolian processes and direct weathering in stream channels and in lake-margin sediments. A major trend to emerge from this analysis is that sources of nutrients ( $\mathrm{N}$ and $\mathrm{P}$ ) in the McMurdo Dry Valleys are often decoupled from the biota that facilitate their transformation and the availability of liquid water that controls their transport. Thus the material budgets of the dry valleys and their stoichiometry may only be elucidated by understanding biogeochemical and hydrological linkages among aquatic and terrestrial systems.

\subsection{Soil Age and Ecosystem Stoichiometry \\ 4.1.1. Sources of $\mathbf{N}$ and $P$}

[24] Soils are a critical landscape unit in ecosystem stoichiometry because they maintain a large reservoir of $\mathrm{C}, \mathrm{N}$ and $\mathrm{P}$ relative to adjacent aquatic ecosystems. In the dry valleys, soils are an important source of nutrients to glaciers [Lyons et al., 2003], streams [Gooseff et al., 2002], and lakes [Fritsen et al., 2000], influencing rates of nutrient input and biological production. For example, eolian fluxes of sediment in the Taylor Valley are $1-100 \mathrm{~g} \mathrm{~m}^{-2} \mathrm{yr}^{-1}$ [Lancaster, 2002], resulting in a total redistribution of $1-200 \mathrm{~kg} \mathrm{yr}^{-1}$ of $\mathrm{P}$ between soils and lakes in Taylor
Valley (Table 4). Considering the large range of $\mathrm{C}, \mathrm{N}$ and $\mathrm{P}$ ratios found in dry valley soils, spatial variation in soil nutrients and their inputs to aquatic systems likely contributes to the widely different nutrient ratios of aquatic ecosystems observed among the basins and valleys.

[25] The increase in $\mathrm{N}$ content observed along the soil chronosequence is likely due to an accumulation of atmospherically derived salts in soil surfaces where arid conditions limit leaching [Bockheim, 1997] and presumably prohibit denitrification. High concentrations of inorganic $\mathrm{N}$ relative to total $\mathrm{N}$ are a distinctive feature of dry valley soils and indicate that physical processes (deposition) operating over long timescales without significant biotic modification or physical loss can generate element ratios that depart markedly from biological stoichiometry. Large concentrations of salt combined with low organic $\mathrm{C}$ availability may prohibit colonization by soil fauna (Figure 3) [Nkem et al., 2006]. These saline soils occur in the coldest and driest ecosystems in the dry valleys suggesting that climate severity may also limit invertebrate distribution. However, soil invertebrate communities have been reported as far south as $83^{\circ} \mathrm{S}$ in the vicinity of the Beardmore Glacier where conditions are presumably much colder and also drier [Adams et al., 2006], indicating that climate severity alone is insufficient to account for differences in habitat suitability among terrestrial Antarctic ecosystems.

[26] In contrast to ancient, saline soils, young soils had low inorganic $\mathrm{N}$ concentrations, but high soil $\mathrm{P}$ (Figure 2). Calcium-bound $\mathrm{PO}_{4}^{-3}$ pools dominate soil $\mathrm{P}$ budgets for all soils reported in Taylor Valley [Blecker et al., 2006], indicating that while $\mathrm{P}$ is abundant in bulk soils, relatively little of it is directly available to biota. The high $\mathrm{P}$ content of the Fryxell basin is associated with the youngest glacial tills in Taylor Valley [Campbell and Claridge, 1987; Gudding, 2003]. Estimates of soil P reservoirs based on till composition and mineralogy show that the high $\mathrm{P}$ concentrations of the Lake Fryxell basin cannot be accounted for on the basis of parent material mineralogy alone, but are likely a function of the young soil age [Gudding, 2003]. Soils occurring on young tills in the vicinity of Lake Fryxell are also among the most favorable for biological activity [Virginia and Wall, 1999; Parsons et al., 2004; Barrett et al., 2006]. In addition, soils in the Fryxell basin have higher concentrations of weathered P fractions (soluble, Al-bound, Fe-bound, and organic $\mathrm{P}$ fractions) relative to a site in the Lake Bonney basin [Blecker et al., 2006]. Thus the relatively young soils of the Fryxell basin have the highest bulk soil $\mathrm{P}$ and biologically available $\mathrm{P}$.

\subsubsection{Controls Over Soil $N$ and $P$ Cycling}

[27] The highly imbalanced stoichiometry of some dry valley soils indicates little biotic control over bulk element ratios in soil ecosystems and may be a general characteristic of extreme environments. For example, N:P ratios are well below the nutrient ratios of soil organisms exhibiting balanced growth (Table 2). These imbalances are most strongly expressed in geologically young soils where $\mathrm{P}$ concentrations are highest and in older soils where concentrations of $\mathrm{N}$ (as $\mathrm{NO}_{3}^{-}$) exceed $\mathrm{C}$ concentrations (Figure 2). This broad range of soil $\mathrm{N}$ content observed is striking, and results in widely varying soil $\mathrm{C}$ : $\mathrm{N}$ ratios $(0.02$ to 30 ) among different valleys (Figure 3 ), directly related to high soil $\mathrm{NO}_{3}^{-}$concentrations in the older, higher-elevation 


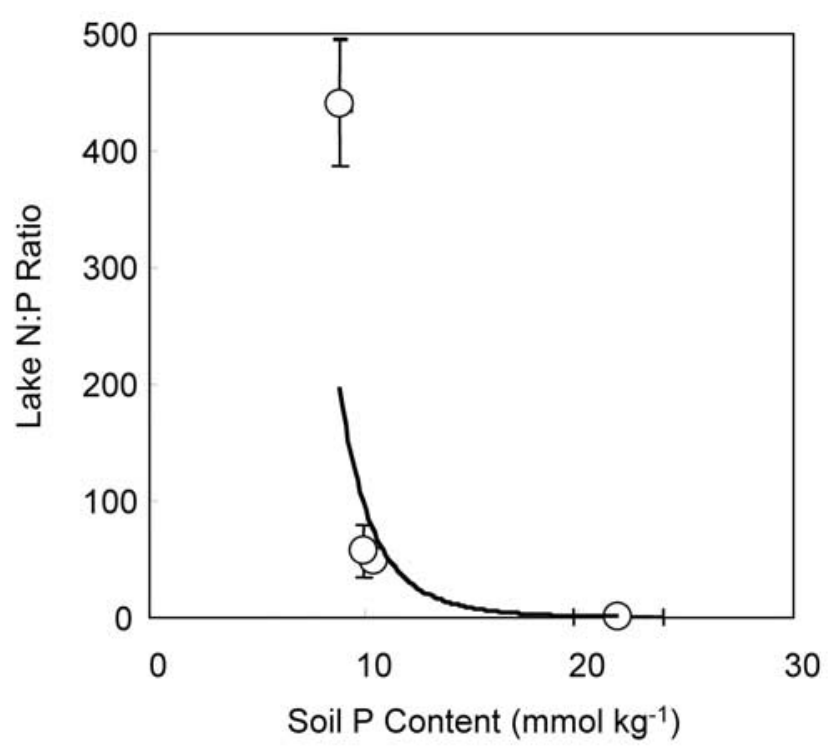

Figure 5. Plot of lake surface water N:P ratios and soil $P$ content for (from highest to lowest lake N:P): Lake Bonney, Joyce (Pearse Valley), Hoare, and Fryxell. The fitted line is a power function that accounts for $74 \%$ of the variance in lake $\mathrm{N}: \mathrm{P}$ ratios as a function of soil $\mathrm{P}$ (Lake $\mathrm{N}: \mathrm{P}=$ $\left.5563 \mathrm{e}^{-0.40 \text { Soil P }}, P=0.044\right)$.

valleys. The dry valleys have high concentrations of inorganic $\mathrm{N}$, especially as $\mathrm{NO}_{3}^{-}$in surface soils relative to dry temperate soils [Virginia et al., 1982]. High $\mathrm{NO}_{3}^{-}$accumulation is a common feature of arid landscapes because of low-biotic potentials for denitrification [Virginia et al., 1982; Walvoord et al., 2003] resulting in a geochemically mediated stoichiometry. In contrast, concentrations of total and organic $\mathrm{N}$ in most of the dry valley soils examined were low compared to nutrient concentrations and availability in temperate soils, but are often high relative to the organic $\mathrm{C}$ content (Table 2), generating elemental ratios that departed widely from biological stoichiometry. The only other terrestrial systems with comparably imbalanced stoichiometry (low C, high $\mathrm{N}$, high $\mathrm{P}$ ) are the hyper-arid soils of the Atacama Desert [Ehleringer et al., 1992], which are a hot desert analog of the dry valleys, and ornithogenic soils (high $\mathrm{C}$, very high $\mathrm{N}$, very high $\mathrm{P}$ ) in avian rookeries of Antarctic maritime regions [Cocks et al., 1998; Barrett et al., 2006].

[28] Differences in biological activity and surface age are associated with significant variability in concentrations of surface soil $\mathrm{C}, \mathrm{N}$ and $\mathrm{P}$ content, as well as the ratios of these elements among the sites in Taylor, Pearse, Beacon and Arena Valleys. Soil organic $\mathrm{C}$ content decreased across the age gradient, coinciding with increasing elevation and climatic severity [Doran et al., 2002b] and decreasing biological activity and biodiversity [Virginia and Wall, 1999; Parsons et al., 2004]. Trends in $\mathrm{N}$ and $\mathrm{P}$ availability evoke a pattern similar to the model of $\mathrm{N}$ and $\mathrm{P}$ retention and ecosystem evolution of Vitousek and Farrington [1997] and Wardle et al. [2004], but result from different mechanisms. While biology $\left(\mathrm{N}_{2}\right.$ fixation, and $\mathrm{N}$ and $\mathrm{P}$ immobilization/retention) can account for trends in the accumulation and retention of nutrients in temperate and tropical ecosystems, the range of $\mathrm{N}$ and $\mathrm{P}$ in the dry valley soils is largely determined by geochemical controls including atmospheric deposition [Michalski et al., 2005] and landscape age or weathering stage (Figure 2).

\subsection{Hydrological Influences Over Stoichiometry \\ 4.2.1. Sources of $\mathbf{N}$ and $P$ in Aquatic Ecosystems}

[29] Landscape position is an important control over the stoichiometry of both aquatic and terrestrial ecosystems in the dry valleys. For example, surface $\mathrm{P}$ concentration of Taylor Valley glaciers varied with local soil $\mathrm{P}$ content and the composition of eolian sediments (Table 4). Commonwealth Glacier, the only glacier where surface $\mathrm{P}$ was detectable, is located in the Fryxell basin where soil P content is the highest in Taylor Valley. Gudding [2003] also showed that the $\mathrm{P}$ content of eolian sediments is greatest in the Fryxell basin and decreases along the NE-SW axis of Taylor Valley. Similar influences of surrounding landscapes on geochemistry have been reported by Lyons et al. [2003] and Mulvaney and Wolff [1994] who noted the importance of geography on surface glacier and stream chemistry in this region, mainly as a function of altitude and proximity to ocean water.

[30] The closed-catchment lakes of the dry valleys integrate the biogeochemical stoichiometry of the glaciers, streams and sediments of the basins they drain. Marked differences in lake hydrology, chemistry, profiles and biology are legacies of past climate history and of their landscape position [Priscu, 1995; Lyons et al., 2000]. An east-west trend in increasing N:P ratios observed for soil, glacier and stream water chemistry is reflected in the surface chemistry of Taylor Valley lakes [Priscu, 1995]. Long-term (1993-2001) mean surface water $(5 \mathrm{~m}) \mathrm{N}: \mathrm{P}$ ratios are: 18 , 71, 632 and 357 for Lakes Fryxell, Hoare and the east and west lobes of Lake Bonney, respectively [Foreman et al., 2004], concurrent with an inverse trend in soil P content (Figure 5). Only in the Fryxell basin, where soils contain a surfeit of $\mathrm{P}$ do streams and lake water maintain N:P in the range of the Redfield ratio (Figure 5). This trend suggests that elemental stoichiometry and productivity in lakes may be limited by a set of factors including the $\mathrm{P}$ content in surrounding soils, the processing of $\mathrm{P}$ within adjoining streams, and mechanisms of $\mathrm{P}$ redistribution among these landscapes. Based upon this observation, we hypothesize that the geochemical stoichiometry of inputs to a given system, i.e., eolian sediments, surface glacial chemistry, stream discharge, provide a first-order constraint on nutrient availability and biological productivity [McKnight et al., 1999; Lyons et al., 2003], while subsequent biotic uptake and mineralization of nutrients in the water column may determine the elemental ratios of "downstream" fluxes. Each component of this hydrological continuum transforms the chemistry of the through-put according to the degree of biological modification or activity along the flow path (Figure 6).

\subsubsection{Controls Over Stoichiometry in Aquatic Ecosystems}

[31] Biotic influences on stoichiometry were most apparent through changes in the relative concentration of nutrients in water moving across the major aquatic landscapes of Taylor Valley, i.e., the hydrologic continuum of glaciers, streams, and lakes (Figure 6). The elemental stoichiometry of glacial melt is influenced by the chemistry 


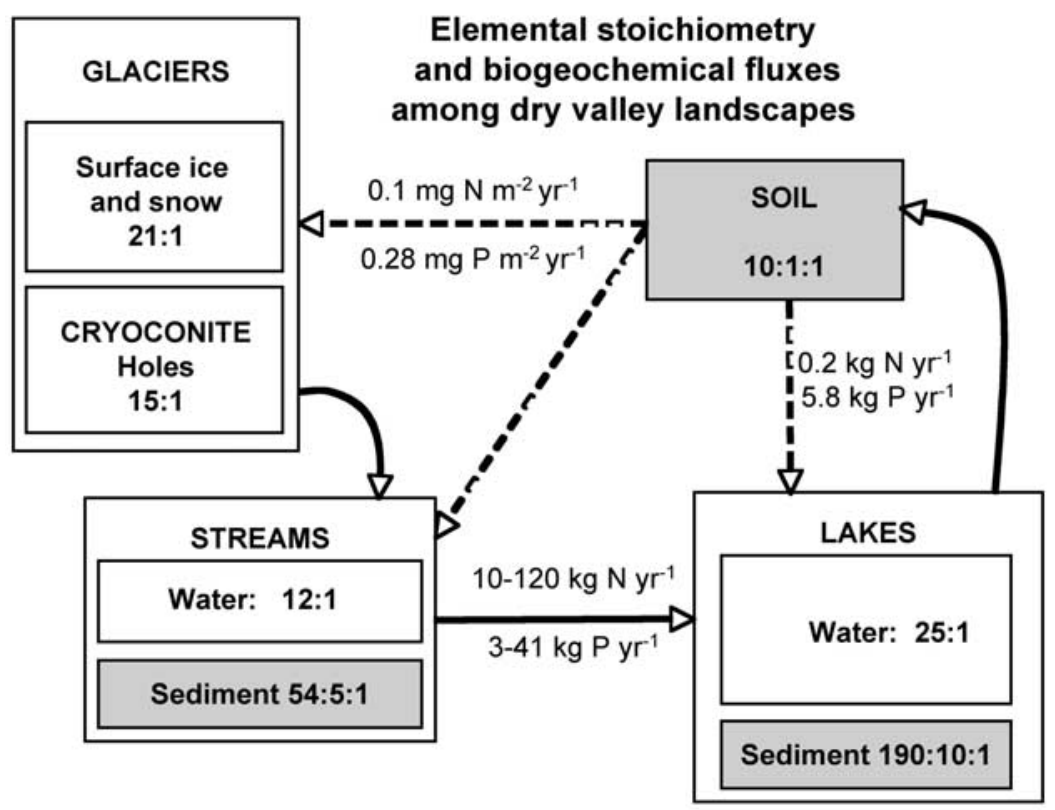

Figure 6. Average molar N:P or $\mathrm{C}: \mathrm{N}: \mathrm{P}$ ratios and biogeochemical fluxes among landscape units in eastern Taylor Valley, Antarctica. Estimated and theoretical aqueous fluxes are depicted by solid arrows, eolian fluxes by dashed arrows. A general narrowing of N:P ratios illustrates a biological modification of melt water along this hydrological continuum closer to the ratio of microbial biomass. Lakes, as the bottom of this hydrological continuum, integrate the legacies of geology and climate resulting in unique lake chemistries and stoichiometry in each basin contingent upon the chemistry of surface soils and tills and its climate history. Eolian fluxes of $\mathrm{N}$ and $\mathrm{P}$ among these landscapes are presented in Table 4. Lake nutrient loading data are from [Foreman et al., 2004], cryconite data are calculated from Tranter et al. [2004]; stream and lake sediment data are from Lawson et al. [2004].

of the source material as well as by internal biological transformations occurring in surface ice and cryoconite holes [Tranter et al., 2004]. Glacial cryoconite ecosystems appear to initiate the biological alteration of waters that continues downstream along the hydrological continuum. For example, Tranter et al. [2004] reported lower concentrations of DIN and $\mathrm{PO}_{4}^{-3}$ in cryoconites relative to surface glacier ice on the Canada and Taylor Glaciers, presumably due to biological uptake. The N:P ratios of cryoconite waters are also quite different from the surface glacial ice, suggesting biological processing of nutrients. On the Canada glacier, Tranter et al. [2004] report DIN and $\mathrm{PO}_{4}^{-3}$ concentration generating N:P ratios of 146 for glacier ice and 25 for cryoconites. The data indicate that cryoconite biota alter the glacier ice chemistry by converting $\mathrm{N}$ to organic forms and generating inorganic N:P ratios closer to the stoichiometry of microbial biomass, i.e., 16:1. Cryoconite holes occupy $7 \%$ of the glacier surfaces in Taylor Valley [Fountain et al., 2004] and therefore may have an important influence over the stoichiometry of glacial melt water and nutrient through-flow.

[32] Steam water chemistry reflects glacial melt water composition [McKnight et al., 1999; Lyons et al., 2003], but is also influenced by internal processes within streams, controlling the nutrient input to lakes (Figure 6). Stream waters are elevated in both $\mathrm{N}$ and $\mathrm{P}$ relative to surface glacier ice, indicating the important role of streams as conduits of weathered material from soils and sediments.
Soils exchange nutrients in the active layers and hyporheic zones adjacent to stream channels, contributing to the influence of parent material on stream stoichiometry [Runkel et al., 1998; McKnight et al., 1999; Gooseff et al., 2002]. Parent material and glacial melt effects on stream chemistry are modified by microbial mats which influence the nutrient load of stream water through $\mathrm{N}_{2}$ fixation, immobilization, and denitrification [Gooseff et al., 2004; McKnight et al., 2004]. It is notable that the linear regression of DIN vs. SRP, i.e., the N:P ratio of stream waters, was significant only in streams with abundant algal mats (Figure 4). Similarly, the linear regression of N vs. P was significant only in soils with invertebrate communities (Figure 3). Together these results demonstrate that there are connections between biogeochemical stoichiometry and resident biota in the dry valleys, though these relationships may differ between aquatic and terrestrial ecosystems. It appears that biota influence the elemental ratio of stream waters, while geochemical stoichiometry $(\mathrm{C}: \mathrm{N})$ evidently limits the distribution of soil invertebrates.

[33] The elemental stoichiometry of microbial mats, largely composed of cyanobacteria of the genera Nostoc, Oscillatoria and Phormidium is very close to the Redfield ratios of C:N:P for marine phytoplankton and heterotrophic bacteria [Goldman and Dennett, 2000; Makino and Cotner, 2004]. The influence of mats and hyporheic processing on stream water chemistry was shown by McKnight et al. [2004] by adding $\mathrm{NO}_{3}^{-}, \mathrm{PO}_{4}^{-3}$ and $\mathrm{Cl}^{-}$to Green Creek 
(a stream with high mat density). Following these additions, stream $\mathrm{NO}_{3}^{-}$and $\mathrm{PO}_{4}^{-3}$ levels declined rapidly downstream relative to a conservative $\mathrm{Cl}^{-}$tracer. The combined influence of algal mats and subsurface microbial communities on stoichiometry is to immobilize nutrients in proportion to the ratios necessary to sustain balanced growth and metabolism.

[34] Stream discharge is important to lake nutrient balance because nutrient uptake and retention by mats and the hyporheic zone vary with flow volume; nutrient retention is less efficient during high-flow events than during low to moderate flows [Foreman et al., 2004]. For example, the highest nutrient loading to Lake Fryxell since the LTER began monitoring stream flow in 1993 occurred during the 2001-2002 austral summer when Taylor Valley experienced unusually high temperatures and a high rate of glacial melt. Rates of and N- and P-loading to Lake Fryxell increased by more than tenfold during this season [Foreman et al., 2004].

[35] In typical flow years, approximately half of lake primary production is supported by a combination of advective nutrient loading from streams and glacier melt [Priscu, 1995; Takacs et al., 2001]. Redistribution of eolian sediments [e.g., Fritsen et al., 2000; Lancaster, 2002; Sleewaegen et al., 2002], could provide a significant bulk nutrient source to lake surfaces equal to stream discharges of low-flow years (Table 4 and Figure 6). However, this form of nutrient loading represents a particulate input to lake surface ice, which likely is less accessible to lake biota than the input of dissolved stream nutrients. Sediments of the hydrological margins at the interface of lakes and soils are an additional source of nutrients to dry valley lakes, considering the rates of weathering and nutrient exchanges reported for stream hyporheic zones [Gooseff et al., 2002; Maurice et al., 2002]. Priscu [1995] showed that maximum levels of chlorophyll and primary productivity in Taylor Valley lakes occurred at a depth determined by the balance between light attenuation with depth and diffusive flux from nutrient rich bottom water, indicating that the upward diffusion of nutrients from highly saline bottom water across the chemocline provide a significant source of nutrients to these hyper-oligotrophic ecosystems. Thus a large proportion of contemporary lake production is supported by an upward flux of legacy nutrients and particulate organic matter deposited $10^{3}-10^{6}$ years ago and is linked to exchanges between lake and soil landscapes that occurred during the late Pleistocene [Priscu, 1995; Poreda et al., 2004].

\subsection{Ecological Legacies and Stoichiometry}

[36] Soils are linked to the hydrological continuum directly at the hyporheic zones of streams [McKnight et al., 1999; Gooseff et al., 2002]. However the overall affect of soils on the biogeochemistry of dry valley ecosystems may be more significant through indirect mechanisms such as eolian redistribution and through the cycles of lake expansion, inundation and recession operating on decadal to millennial timescales [Doran et al., 1999; Burkins et al., 2000; Lyons et al., 2000; Doran et al., 2002a; Fountain and Lyons, 2003]. Lake level fluctuations also alter soil stoichiometry where lacustrine sediments have been deposited on soils. Soil organic matter bears an isotopic signature $\left(\delta^{15} \mathrm{~N}\right.$ and ${ }^{13} \mathrm{C}$ ) closely resembling lake mat material. This is true particularly at low elevations close to the contemporary lake edges, which are presumably the sites of the most recent deposition as the lakes recede [Burkins et al., 2000; Lawson et al., 2004]. Since dry valley soils are enriched in N and P relative to organic $\mathrm{C}$, and lake systems are $\mathrm{N}$ and $\mathrm{P}$ limited, a transfer of nutrients may have proceeded over cycles of lake fluctuation with lakes contributing moat and benthic sediments rich in C to soils [Lawson et al., 2004] and in return acquiring $\mathrm{N}$ and $\mathrm{P}$. Thus the long-term productivity of lake and soil ecosystems may rely on these nutrient exchanges facilitated by changes in lake volume over $10^{2}-10^{4}$ yrs.

[37] If evolution of the dry valley ecosystem is linked with landscape development and climate variation over geologic timescales, what can we predict about the stoichiometric future of the dry valleys under current climate conditions? Recent evidence supports a net cooling trend since 1985, with increasing lake ice thickness, lake drawdown, and decreases in biological activity occurring during the 1990s [Doran et al., 2002a]. Given the reconstruction of glacier and lake history, cooling temperatures would reduce the melt-water generation, and therefore reduce the volume of saturated sediments at the margins between aquatic and terrestrial landscapes and thus the delivery of nutrients (particularly P) to lakes. Such a trend would shift Taylor Valley toward colder, drier conditions similar to Beacon and Arena Valleys. In contrast, abrupt seasonal warming, as occurred during the summer of 2001-2002 caused the volume of annual stream discharge to increase to that of $2 \mathrm{X}$ the previous 8 yrs combined; in response, $\mathrm{P}$ loading was up to 10 -fold greater than previous loading rates [Jaros, 2003; Foreman et al., 2004]. This single "warm" season offset the declining lake levels experienced during the cool and dry 1990s. Both cooling and warming responses illustrate the contingent nature of climate controls over dry valley biogeochemistry, where the events of one season can offset the accumulated effects of the previous decade.

\section{Conclusions}

[38] A static view of element ratios in the McMurdo Dry Valleys suggests that physical processes dominate a geochemical stoichiometry of soil and aquatic ecosystems, as illustrated by the imbalanced ratios of some soils. However, the protoplasmic organisms that comprise dry valley food webs adhere to strict biochemical requirements in the composition of their biomass, and when activated by the availability of liquid water influence the chemical composition of their environment. Thus we can detect the influence of biological processes on biogeochemical stoichiometry, and this influence is constrained by the availability of liquid water. Here we have developed a conceptual model describing variation in elemental ratios and nutrient transformations among aquatic and terrestrial landscapes of the McMurdo Dry Valleys (Figure 6). From this model we hypothesize that the elemental composition of inputs to a given system, i.e., N:P of eolian sediments, surface glacial chemistry, and/or stream discharge, constrain biological productivity, while subsequent biotic uptake and mineralization of nutrients in the water column determine the elemental ratios of "downstream" fluxes and nutrient availability. For example, spatial variation in soil nutrients 
and their inputs to aquatic systems contributed to the widely different nutrient ratios of stream and lake systems observed among the basins and valleys. Lake stoichiometry in particular may be strongly linked to the age of the surrounding till and weathering processes occurring in the adjacent streams and sediments. Over long timescales (i.e., glacial-interglacial), periodic lake inundation and recession redistribute $\mathrm{C}$, $\mathrm{N}$, and $\mathrm{P}$ among aquatic and terrestrial ecosystems and sustain the long-term productivity of dry valley ecosystems.

[39] Acknowledgments. This paper was inspired by discussion with the 2001 LTER Site Review Team. We thank especially P. Vitousek for his insightful comments and suggestions. Many people contributed to the collection and processing of the data presented in this paper, most notably K. Welch, M. Tranter, J. Lawson, A. Parsons, T. Nylen, R. Edwards, C. Wolf, and P. Zietz. We especially appreciate the help of J. Gudding, who redirected her research in order to assist with the work presented here, and M. Gooseff, who provided comments on an earlier draft of this manuscript. We thank Antarctic Support Associates, Raytheon Polar Services, and Petroleum Helicopters Inc. for logistical support. This paper is a contribution to the National Science Foundation sponsored McMurdo LTER Program (OPP 9810219 and 0096250).

\section{References}

Adams, B. J., et al. (2006), Diversity and distribution of Victoria Land biota, Soil Biol. Biochem., 38, 3003-3018.

Alger, A. S., et al. (1997), Ecological processes in a cold desert ecosystem: The abundance and species of algal mats in glacial meltwater streams in Taylor Valley, Antarctica, Occas. Pap. 51, Inst. of Arct. and Alp. Res., Boulder, Colo.

Aspila, K. I., H. Agemian, and A. S. Y. Chau (1976), Semiautomated method for determination of inorganic, organic and total phosphate in sediments, Analyst, 101, 187-197.

Bamforth, S. S., D. H. Wall, and R. A. Virginia (2005), Distribution and diversity of soil protozoans in the McMurdo Dry Valleys, Antarctica, Polar Biol., 28, 756-762.

Barrett, J. E., et al. (2006), Terrestrial ecosystem processes of Victoria Land, Antarctica, Soil Biol. Biochem., 38, 3019-3034.

Blecker, S. W., J. A. Ippolito, J. E. Barrett, D. H. Wall, R. A. Virginia, and K. L. Norvell (2006), Phosphorus fractionation implications in soils of Taylor Valley, Antarctica, Soil Sci. Soc. Am. J., 70, 806-815.

Bockheim, J. G. (1997), Properties and classification of cold desert soils from Antarctica, Soil Sci. Soc. Am. J., 61, 224-231.

Bockheim, J. G. (2002), Landform and soil development in the McMurdo Dry Valleys, Antarctica: A regional synthesis, Arct. Antarct. Alp. Res., 34, $308-317$.

Burkins, M. B., R. A. Virginia, C. P. Chamberlain, and D. H. Wall (2000), Origin and distribution of soil organic matter in Taylor Valley, Antarctica, Ecology, 81, 2377-2391

Burkins, M. B., R. A. Virginia, and D. H. Wall (2001), Organic carbon cycling in Taylor Valley, Antarctica: Quantifying soil reservoirs and soil respiration, Global Change Biol., 7, 113-125.

Campbell, I. B., and G. G. C. Claridge (1987), Antarctica: Soils, Weathering Processes and Environment, Dev. Soil Sci., vol. 16, Elsevier, New York.

Chadwick, O. A., L. A. Derry, P. M. Vitousek, B. J. Huebert, and L. O. Hedin (1999), Changing sources of nutrients during four million years of ecosystem development, Nature, 397, 491-497.

Cocks, M. P., I. P. Newton, and W. D. Stock (1998), Bird effects on organic processes in soils from five microhabitats on a nunatak with and without breeding snow petrels in Dronning Maud Land, Antarctica, Polar Biol., $20,112-120$

Cowan, D. A., N. J. Russell, A. Mamais, and D. M. Sheppard (2002), Antarctic Dry Valley mineral soils contain unexpectedly high levels of microbial biomass, Extremophiles, 6, 431-436.

Crews, T. E., K. Kitayama, J. H. Fownes, R. H. Riley, D. A. Herbert, D. Muellerdombois, and P. M. Vitousek (1995), Changes in soilphosphorus fractions and ecosystem dynamics across a long chronosequence in Hawaii, Ecology, 76, 1407-1424.

Denton, G. H., J. G. Bockheim, S. C. Wilson, and M. Stuiver (1989), Late Wisconsin and early Holocene glacial history, Inner Ross Embayment, Antarctica, Quat. Res., 31, 151-182.

Doran, P. T., G. W. Berger, W. B. Lyons, R. A. Wharton, M. L. Davisson, J. Southon, and J. E. Dibb (1999), Dating Quaternary lacustrine sediments in the McMurdo Dry Valleys, Antarctica, Palaeogeogr. Palaeoclimatol. Palaeoecol., 147, 223-239.
Doran, P. T., et al. (2002a), Antarctic climate cooling and terrestrial ecosystem response, Nature, 415, 517-520.

Doran, P. T., et al. (2002b), Valley floor climate observations from the McMurdo Dry Valleys, Antarctica, 1986-2000, J. Geophys. Res., 107(D24), 4772, doi:10.1029/2001JD002045.

Dore, J., and J. C. Priscu (2001), Phytoplankton phosphorus deficiency and alkaline phosphatase activity in the McMurdo Dry Valley lakes, Antarctica, Limnol. Oceanogr., 46, 1331-1346.

Ehleringer, J. R., H. A. Mooney, P. W. Rundel, R. D. Evans, B. Palma, and J. Delatorre (1992), Lack of nitrogen cycling in the Atacama Desert, Nature, 359, 316-318.

Filippelli, G. M., and C. Souch (1999), Effects of climate and landscape development on the terrestrial phosphorus cycle, Geology, 27, 171-174.

Foreman, C. M., C. F. Wolf, and J. C. Priscu (2004), Geochemistry of the McMurdo Dry Valleys: Impact of decadal warming events on the geochemical stoichiometry of lakes in the McMurdo Dry Valleys, Aquat. Geochem., 10, 239-268.

Fountain, A. G., and W. B. Lyons (2003), Century to millennial scale climate change and ecosystem response in Taylor Valley, Antarctica, in Climate Variability and Ecosystem Response at Long-Term Ecological Research Sites, edited by D. Greenland, D. G. Goodin, and R. C. Smith, pp. 319-340, Oxford Univ. Press, New York.

Fountain, A. G., et al. (1999), Physical controls on the Taylor Valley ecosystem, Antarctica, Bioscience, 49, 961-971.

Fountain, A. G., M. Tranter, T. Nylen, D. Booth, and K. Lewis (2004), Cryoconite holes on polar glaciers and their importance for meltwater runoff in the McMurdo Dry Valleys, Antarctica, J. Glaciol., 50, 35-45.

Freckman, D. W., and R. A. Virginia (1997), Low-diversity Antarctic soil nematode communities: Distribution and response to disturbance, Ecology, 78, 363-369

Friedmann, E. I., L. Kappen, M. A. Meyer, and J. A. Nienow (1993), Longterm productivity in the cryptoendolithic microbial community of the Ross Desert, Antarctica, Microb. Ecol., 25, 51-69.

Fritsen, C. P., A. M. Grue, and J. C. Priscu (2000), Distribution of organic carbon and nitrogen in surface soils in the McMurdo Dry Valleys, Antarctica, Polar Biol., 23, 121-128.

Goldman, J. C., and M. R. Dennett (2000), Growth of marine bacteria in batch and continuous culture under carbon and nitrogen limitation, Limnol. Oceanogr., 45, 789-800.

Goldman, J. C., J. J. McCarthy, and D. G. Peavey (1979), Growth-rate influence on the chemical composition of phytoplankton in oceanic waters, Nature, 279, 210-215.

Gooseff, M. N., D. M. McKnight, W. B. Lyons, and A. E. Blum (2002), Weathering reactions and hyporheic exchange controls on stream water chemistry in a glacial meltwater stream in the McMurdo Dry Valleys, Water Resour. Res., 38(12), 1279, doi:10.1029/2001WR000834.

Gooseff, M. N., J. E. Barrett, P. T. Doran, W. B. Lyons, A. N. Parsons, D. L. Porazinska, R. A. Virginia, and D. H. Wall (2003), Snow-patch influence on soil biogeochemical processes and invertebrate distribution in the McMurdo Dry Valleys, Antarctica, Arct. Antarct. Alp. Res., 35 , $92-100$.

Gooseff, M. N., D. M. McKnight, R. L. Runkel, and J. H. Duff (2004), Denitrification and hydrologic transient storage in a glacial meltwater stream, McMurdo Dry Valleys, Antarctica, Limnol. Oceanogr., 49 $1884-1895$

Gudding, J. (2003), Phosphorus in Taylor Valley, Antarctica: The connection between landscape age and nutrient limitation in aquatic ecosystem components, Masters thesis, Ohio State Univ., Columbus.

Hall, B. L., and G. H. Denton (2000), Radiocarbon chronology of Ross Sea drift, eastern Taylor Valley, Antarctica: Evidence for a grounded ice sheet in the Ross Sea at the Last Glacial Maximum, Geogr. Ann., Ser. A, 82, 305-336.

Hall, B. L., G. H. Denton, and B. Overturf (2001), Glacial Lake Wright, a high-level Antarctic lake during the LGM and early Holocene, Antarct. Sci., 13, 53-60.

Hall, B. L., G. H. Denton, B. Overturf, and C. H. Hendy (2002), Glacial Lake Victoria, a high-level Antarctic lake inferred from lacustrine deposits in Victoria Valley, J. Quat. Sci., 17, 697-706.

Hassett, R. P., B. Cardinale, L. B. Stabler, and J. J. Elser (1997), Ecological stoichiometry of $\mathrm{N}$ and $\mathrm{P}$ in pelagic ecosystems: Comparison of lakes and oceans with emphasis on the zooplankton-phytoplankton interaction, Limnol. Oceanogr., 42, 648-662.

Hecky, R. E., and P. Kilham (1988), Nutrient limitation of phytoplankton in fresh-water and marine environments-A review of recent-evidence on the effects of enrichment, Limnol. Oceanogr., 33, 796-822.

Hessen, D. O., G. I. Agren, T. R. Anderson, J. J. Elser, and P. C. de Rutter (2004), Carbon sequestration in ecosystems: The role of stoichiometry, Ecology, 85, 1179-1192.

Jaros, C. (2003), Temperature-elevation effect on glacial meltwater generation in McMurdo Dry Valleys, Antarctica, Masters thesis. Univ. of Colo., Boulder. 
Lajtha, K., and W. H. Schlesinger (1988), The biogeochemistry of phosphorus cycling and phosphorus availability along a desert soil chronosequence, Ecology, 69, 24-39.

Lancaster, N. (2002), Flux of eolian sediment in the McMurdo Dry Valleys, Antarctica: A primary assessment, Arct. Antarct. Alp. Res., 34, 318-323.

Lawson, J., P. T. Doran, F. Kenig, D. J. Des Marais, and J. C. Priscu (2004), Stable carbon and nitrogen isotopic composition of benthic and pelagic organic matter in lakes of the McMurdo Dry Valleys, Antarctica, Aquat. Geochem., 10, 296-301.

Laybourn-Parry, J., M. R. James, D. M. McKnight, J. C. Priscu, S. A. Spaulding, and R. Shiel (1997), The microbial plankton of Lake Fryxell, southern Victoria Land, Antarctica during the summer of 1992 and 1994, Polar Biol., 17, 54-61.

Lyons, W. B., A. G. Fountain, P. T. Doran, J. C. Priscu, J. K. Neumann, and K. A. Welch (2000), Importance of landscape position and legacy: The evolution of the lakes ion Taylor Valley, Antarctica, Freshwater Biol., 43, $355-367$.

Lyons, W. B., K. A. Welch, A. G. Fountain, G. L. Dana, B. H. Vaughn, and D. M. McKnight (2003), Surface glaciochemistry of Taylor Valley, southern Victoria Land, Antarctica and its relationship to stream chemistry, Hydrol. Processes, 17, 115-130.

Makino, W., and J. B. Cotner (2004), Elemental stoichiometry of a heterotrophic bacterial community in a freshwater lake: implications fro growth and resource-dependent variations, Aquat. Microb. Ecol., 34, 33-41.

Marchant, D. R., G. H. Denton, C. C. Swisher, and N. Potter (1996), Late Cenozoic Antarctic paleoclimate reconstructed from volcanic ashes in the Dry Valleys region of Southern Victoria Land, Geol. Soc. Am. Bull., 108, $181-194$.

Maurice, P. A., D. M. McKnight, L. Leff, J. E. Fulghum, and M. Gooseff (2002), Direct observations of aluminosilicate weathering in the hyporheic zone of an Antarctic Dry Valley stream, Geochim. Cosmochim. Acta, $66,1335-1347$.

McKnight, D. M., A. S. Alger, C. M. Tate, G. Shupe, and S. Spaulding (1998), Longitudinal patterns in algal abundance and species distribution in meltwater streams in Taylor Valley, Southern Victoria Land, Antarctica, in Ecosystem Dynamics in a Polar Desert: The McMurdo Dry Valleys, Antarctica, Antarct. Res. Ser., vol. 72, edited by J. C. Priscu, pp. 109127, AGU, Washington, D. C.

McKnight, D. M., D. K. Niyogi, A. S. Alger, A. Bomblies, P. A. Conovitz, and C. M. Tate (1999), Dry valley streams in Antarctica: ecosystems waiting for water, BioScience, 49, 985-995.

McKnight, D. M., B. L. Howes, C. D. Taylor, and D. D. Goehringer (2000), Phytoplankton dynamics in a stably stratified Antarctic lake during winter darkness, J. Phycol., 36, 852-861.

McKnight, D. M., R. L. Runkel, J. H. Duff, C. M. Tate, and D. Moorhead (2004), Inorganic nitrogen and phosphorous dynamics of Antarctic glacial meltwater streams as controlled by hyporheic exchange and benthic autotrophic communities, J. N. Am. Benth. Soc., 23, 171-188.

Michalski, G., J. G. Bockheim, C. Kendall, and M. Thiemens (2005), Isotopic composition of Antarctic Dry Valley nitrate: Implications for $\mathrm{NO}_{\mathrm{y}}$ sources and cycling Antarctica, Geophys. Res. Lett., 32, L13817, doi:10.1029/2004GL022121.

Moorhead, D. L., P. T. Doran, A. G. Fountain, W. B. Lyons, D. M. McKnight, J. C. Priscu, R. A. Virginia, and D. H. Wall (1999), Ecological legacies: Impacts on ecosystems of the McMurdo Dry Valleys, BioScience, 49, 1009-1019.

Mulvaney, R., and E. W. Wolff (1994), Spatial variability of the major chemistry of the Antarctica ice sheet, Ann. Glaciol., 20, 440-447.

Nezat, C. A., W. B. Lyons, and K. A. Welch (2001), Chemical weathering in streams of a polar desert (Taylor Valley, Antarctica), Geol. Soc. Am. Bull., 113, 1401-1408.

Nkem, J. N., R. A. Virginia, J. E. Barrett, D. H. Wall, and G. Li (2006), Salt tolerance and survival thresholds for two species of Antarctic soil nematodes, Polar Biol., 29(8), 643-651.

Parsons, A. N., J. E. Barrett, D. H. Wall, and R. A. Virginia (2004), Carbon dioxide flux from Antarctic Dry Valley soils, Ecosystems, 7, 286-295.

Poreda, R. J., A. G. Hunt, W. B. Lyons, and K. A. Welch (2004), The helium isotopic chemistry of Lake Bonney, Taylor Valley, Antarctica: Timing of late Holocene climate change in Antarctica, Aquat. Geochem., $10,353-371$

Priscu, J. C. (1995), Phytoplankton nutrient deficiency in lakes of the McMurdo Dry Valleys, Antarctica, Freshwater Biol., 34, 215-227.

Priscu, J. C., C. F. Wolf, C. D. Takacs, C. H. Fritsen, J. Laybourn-Perry, E. C. Roberts, B. Sattler, and W. B. Lyons (1999), Carbon transformations in a perennially ice-covered Antarctic lake, BioScience, 49, 997-1008.

Redfield, A. C. (1958), The biological control of chemical factors in the environment, Am. Sci., 46, 205-221.
Reiners, W. A. (1986), Complementary models for ecosystems, Am. Nat., $127,59-73$.

Runkel, R. L., D. M. McKnight, and E. A. Andrews (1998), Analysis of transient storage subject to unsteady flow: Diel flow variation in an Antarctic stream, J. N. Am. Benth. Soc., 17, 143-154.

Sleewaegen, S., R. Lorrain, Z. Offer, E. Azmon, S. Fitzsimons, and R. Souchez (2002), Trapping of aeolian sediments and build-up of the ice cover of a dry-based Antarctic lake, Earth Surf. Processes Landforms, 27, $307-315$.

Sterner, R. W., and J. J. Elser (2002), Ecological Stoichiometry: The Biology of Elements From Molecules to the Biosphere, Princeton Univ. Press, Princeton, N. J.

Takacs, C. D., J. C. Priscu, and D. M. McKnight (2001), Bacterial dissolved organic carbon demand in McMurdo Dry Valley lakes, Antarctica, Limnol. Oceanogr., 46, 1189-1194.

Tilman, D. (1985), The Resource-ratio hypothesis of plant succession, Am. Nat., $125,827-852$.

Tranter, M., A. G. Fountain, C. H. Fristsen, W. B. Lyons, J. C. Priscu, P. J. Statham, and K. A. Welch (2004), Extreme hydrochemical condition in natural microcosms entombed within Antarctic ice, Hydrol. Processes, $18,379-387$

Turner, R. E. (2002), Element ratios and aquatic food webs, Estuaries, 25 , 694-703.

Virginia, R. A., and D. H. Wall (1999), How soils structure communities in the McMurdo Dry Valleys, Antarctica, BioScience, 49, 973-983.

Virginia, R. A., W. M. Jarrell, and E. Franco-Vizcaino (1982), Direct measurement of denitrification in a Prosopis (Mesquite) dominated Sonoran desert ecosystem, Oecologia, 53, 120-122.

Vitousek, P. M. (2004), Nutrient Cycling and Limitation: Hawai'i as a Model System, Princeton Univ. Press, Princeton, N. J.

Vitousek, P. M., and H. Farrington (1997), Nutrient limitation and soil development: Experimental test of a biogeochemical theory, Biogeochemistry, 37, 63-75.

Vitousek, P. M., D. R. Turner, and K. Kitayama (1995), Foliar nutrients during long-term soil development in Hawaiian montane rain-forest, Ecology, 76, 712-720.

Vrede, T., D. R. Dobberfuhl, S. A. L. M. Kooijman, and J. J. Elser (2004), Fundamental connections among organisms C:N:P stoichiometry, macromolecular composition, and growth, Ecology, 85, 1217-1229.

Walker, T. W., and J. Syers (1976), Fate of phosphorus during pedogenesis, Geoderma, 15, 1-19.

Walvoord, M. A., F. M. Phillips, D. A. Stonestrom, R. D. Evans, P. C. Hartsough, B. D. Newman, and R. G. Striegl (2003), A reservoir of nitrate beneath desert soils, Science, 302, 1021-1024.

Wardle, D. A., L. R. Walker, and R. D. Bardgett (2004), Ecosystem properties and forest decline in contrasting long-term chronosequences, Science, $305,509-513$.

Wataru, M., and J. B. Cotner (2004), Elemental stoichiometry of a heterotrophic bacterial community in a freshwater lake: Implications for growth- and resource-dependent variations, Aquat. Microb. Ecol., 34, $33-41$.

Welch, K. A., W. B. Lyons, E. Graham, K. Neumann, J. M. Thomas, and D. Mikesell (1996), Determination of major element chemistry in terrestrial waters from Antarctica by ion chromatography, J. Chromatogr., 739 , $257-263$.

Wharton, R. A., Jr., C. P. McKay, G. M. Simmons, and B. C. Parker (1985), Cryoconite holes on glaciers, BioScience, 8, 499-503.

J. E. Barrett, Department of Biological Sciences, Virginia Polytechnic Institute and State University, Blacksburg, VA 24061, USA. (jebarre@vt.edu) P. T. Doran, Earth and Environmental Sciences, University of Illinois at Chicago, Chicago, IL 60607, USA.

A. G. Fountain, Department of Geology and Geography, Portland State University, Portland, OR 97207, USA.

W. B. Lyons, Byrd Polar Research Center, Ohio State University, Columbus, OH 43210, USA.

D. M. McKnight, Institute of Arctic and Alpine Research, University of Colorado, Boulder, CO 80309, USA.

D. L. Moorhead, Earth, Ecological and Environmental Sciences, University of Toledo, Toledo, $\mathrm{OH} 43606$, USA.

J. C. Priscu, Land Resources and Environmental Sciences, Montana State University, Bozeman, MT 59717, USA.

R. A. Virginia, Environmental Studies Program, Dartmouth College, Hanover, NH 03755, USA.

D. H. Wall, Natural Resource Ecology Laboratory, Colorado State University, Ft. Collins, CO 80523, USA. 